Vol. 8 (1999): 253-263.

\title{
Effect of enlarged cage space and access to earthen floor on locomotor and digging activity of blue foxes
}

\author{
Hannu Korhonen \\ Agricultural Research Centre of Finland, Animal Production Research, Fur Animals, FIN-69100 Kannus, \\ Finland, e-mail: hannu.t.korhonen@mtt.fi \\ Lauri Jauhiainen \\ Agricultural Research Centre of Finland, Data and Information Services, FIN-31600 Jokioinen, Finland \\ Paavo Niemelä \\ Agricultural Research Centre of Finland, Animal Production Research, Fur Animals, FIN-69100 Kannus, Finland
}

\begin{abstract}
The experiment was carried out in order to clarify rebound effect of different-sized wire-mesh cages and access to an earthen floor on activity, floor preference and digging motivation in adult male blue foxes (Alopex lagopus). The experimental set-up employed a construction in which the solitary animal spent the first 2 weeks in a small, raised wire-mesh floored cage $(80 \mathrm{~cm}$ long x $105 \mathrm{~cm}$ wide $\mathrm{x} 70$ $\mathrm{cm}$ high). Thereafter, cage length was enlarged from 80 to $120 \mathrm{~cm}$ for a further 2 weeks and then to $240 \mathrm{~cm}$. Finally, the fox also had free access to an earthen floor cage at ground level $(80 \mathrm{~cm}$ long $\mathrm{x}$ $105 \mathrm{~cm}$ wide $\mathrm{x} 70 \mathrm{~cm}$ high). The behaviour of each experimental animal was video-recorded for 240 hours in each housing option. The results showed that the amount of locomotor activity did not significantly increase despite enlarged cage space and access to the earthen floor. Seventy five $\%$ of activity bouts were no longer than 6 minutes. The shortest bouts were observed in large cage with access to an earthen floor. Foxes significantly preferred a raised wire-mesh floor to an earthen floor at ground level. Provision of an earthen floor did not motivate foxes to dig.
\end{abstract}

Key words: Alopex lagopus, cage size, digging, motivation, preferences, rebound effect

\section{Introduction}

Housing conditions of farmed blue foxes (Alopex lagopus) should cater to their behavioural needs. It has been recently stated that these needs cannot be fully satisfied in traditional shed cages and that improvements aimed to enhance wel- fare are required (European Convention 1991). Development work should focus on two main criteria, i.e. quantity and quality components of the available cage micro-environment (Braastad 1992, Bakken et al. 1994). Quantity refers to the amount of housing space required (Wiegand et al. 1994). The crucial question to be answered is: how much living space do cage-confined 
Korhonen, H. et al. Effect of enlarged cage space on blue foxes

foxes need to exercise and maintain their wellbeing? Space quality refers to the features which enrich the simple housing environment (Wiegand et al. 1994). In this regard, equipment such as year-round resting platforms and nestboxes have been examined (Harri et al. 1991, Mononen et al. 1995, 1996, Korhonen et al. 1995, 1996, Korhonen and Niemelä 1996a, b, c). Recent demands for improved space quality in farmed blue foxes also call for the replacement of cages with wiremesh floors by earthen floors. The first argument for this is that blue foxes are expected to have difficulties to exercising adequetly on wire-mesh flooring. However, this claim has not been substantiated. In a choice experiment in which a wire-mesh floor cage was equipped with a transit tunnel allowing free access to an earthen pen, blue foxes used both sections quite frequently for locomotion, but preferred wire-mesh floor for resting (Korhonen and Niemelä 1997). Similarly, Skovgaard et al. $(1995,1997)$ found that blue foxes born on wire-mesh cage tended to rest on a wire mesh floor more than on a solid floor. However, no significant preference in active behaviour for floor material was evident. Further preference tests comparing wire-mesh and sand-peat floors in silver foxes did not reveal a distinct preference for either floor material (Harri et al. 1996). However, floors above the ground were most often preferred over lower ones despite having floor material. The second argument against wire-mesh flooring is that digging is an important need of foxes, but they are prevented from doing so by their barren cage environment. Access to an earthen floor might be a potential trigger to motivate digging behaviour as observed, for example, in pigs (Appleby and WoodGush 1988). However, in blue foxes, only one study has been conducted to assess and evaluate this argument (Korhonen et al. 1998). This particular study was conducted with male foxes given free access from the raised wire-mesh floor cage to an earthen floor cage at ground level for a 2 week period. Only two out of eight blue foxes dug during the study. One fox spent a total of 145 min digging that was divided over three different days. The other fox was observed to dig on two different days for a total of $29 \mathrm{~min}$. Thus, blue foxes born on wire-mesh cages were not very motivated to dig. More experiments will need to be carried out in order to substantiate this conclusion.

The present behavioural study employed an experimental set-up with gradually increasing wire-mesh cage from the accepted minimum size to a practical maximum that a traditional shed cage unit can hold, and finally also included free access to an earthen floor cage. The aims were to test the following hypotheses in the case of farm-raised blue foxes: 1) if minimum size cage restricts locomotor activity of foxes, then access to a more spacious cage would enhance possibilities for movement, resulting in an increase in activity; 2) if wire-mesh floor is an inappropriate cage flooring surface for living and locomotion, simultaneous access to wire-mesh and earthen floors would demonstrate a preference for the earthen floor; and 3) if digging is a crucial need of farm foxes, access to an earthen floor would stimulate digging. The general theoretical background particularly for the hypotheses 1 and 3 is derived from the theory of Lorenz (1981) which states that when an individual has not had the opportunity to perform a specific behaviour for an extended period of time, the drive to perform that behaviour becomes more intense, or "dams-up". Hypotheses 2 can also be related to an immediate sensory feedback from feet and ventral surface, i.e how comfortable it is to be on a wire-mesh compared to a ground floor.

\section{Material and methods}

\section{Subjects and general management}

The experiment was carried out at the Fur Farming Research Station of Kannus, in western Finland $\left(63.54^{\circ} \mathrm{N}, 23.54^{\circ} \mathrm{E}\right)$, with eight adult male blue foxes (born in May 1995). The study period was from May 3rd to June 29th, 1996. Dur- 
Vol. 8 (1999): 253-263.

ing this period the activity of foxes can be considered to be constant (Korhonen and Niemelä 1998). The experimental animals were randomly selected from the farm stock of about 60 breeding males. None of experimental animals were siblings. Before experimentation they were housed singly in conventional farm cages $(80 \mathrm{~cm}$ long x $105 \mathrm{~cm}$ wide x $70 \mathrm{~cm}$ high) with wiremesh floors. None of foxes had previous experience with an earthen surface. Fresh-mixed fox feed manufactured by the local feed kitchen (Kannus Minkinrehu Ltd.) was supplied once a day (at 1300) from a feed machine. Daily feed portions were about $400 \mathrm{~g} / \mathrm{animal}$. Feed was mainly composed of slaughter-house offal, fish and cereals (Berg 1986). Water was freely available from water cups. Foxes were weighed on a Lario $30 \mathrm{~kg}$ balance (accuracy $\pm 20 \mathrm{~g}$ ) before the start of the experiment. Initial body weights of the blue foxes varied from 7.5 to $10.1 \mathrm{~kg}$. All animals remained healthy throughout the study.

\section{Experimental set-up}

Test cages were placed in the same two-row shed, one behind the other on the left row in relation to the entrance door. The right row was left open to accommodate the video recording equipment. The experimental set-up employed a novel construction (see further Fig. 1) in which each individual spent the first 2 weeks in a small, raised wire-mesh cage (called as small cage; option A in Fig 1.) (80 cm long x $105 \mathrm{~cm}$ wide $x 70 \mathrm{~cm}$ high). Thereafter, cage length was increased to $120 \mathrm{~cm}$ for a further 2 weeks (medium cage; option $\mathrm{A}+\mathrm{B}$ ), and then to total $240 \mathrm{~cm}$ (large cage; option $A+B+C$ ). Cage space was enlarged by removing the walls between cage options. The floor of wire-mesh cages was located $80 \mathrm{~cm}$ above ground level in a conventional shed. Finally, animals also had free access to an earthen floor (80 cm long x $105 \mathrm{~cm}$ wide x $70 \mathrm{~cm}$ high) (D) located on the ground directly below the experimental wire-mesh cages. Access was provided by making a hole $(30 \mathrm{~cm} \mathrm{x} 40 \mathrm{~cm})$ to the cage floor. A wire-mesh was placed about $30 \mathrm{~cm}$

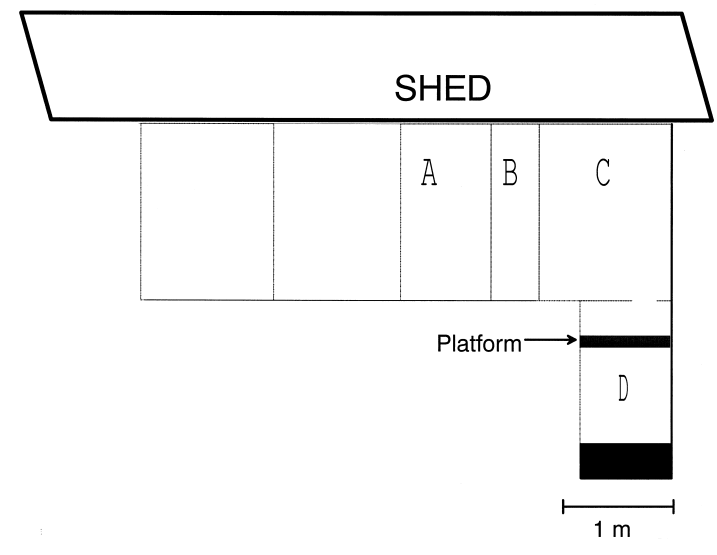

Fig. 1. Schematic diagram of the experimental set-up. Option A is small cage: $80 \mathrm{~cm}$ x $105 \mathrm{~cm}$ x $70 \mathrm{~cm}(\mathrm{~L} \mathrm{x} \mathrm{W} \mathrm{x}$ $\mathrm{H}$ ); option $\mathrm{A}+\mathrm{B}$ is medium cage: $120 \mathrm{~cm} \mathrm{x} 105 \mathrm{~cm} \mathrm{x}$ $70 \mathrm{~cm}$; option $\mathrm{A}+\mathrm{B}+\mathrm{C}$ is large cage: $240 \mathrm{~cm} \mathrm{x} 105 \mathrm{~cm} \mathrm{x}$ $70 \mathrm{~cm}$; fourth option is large cage $A+B+C(240 \mathrm{~cm} \mathrm{x}$ $105 \mathrm{~cm} \mathrm{x} 70 \mathrm{~cm})$ with an earth floor cage $(80 \mathrm{~cm} \mathrm{x}$ $105 \mathrm{~cm} \mathrm{x} 70 \mathrm{~cm}$ ) at ground level (D).

in depth beneath the ground to prevent foxes escaping. The earthen floor cage also contained a wire-mesh platform $(25 \mathrm{~cm}$ wide x $105 \mathrm{~cm}$ long) situated about $25 \mathrm{~cm}$ below the shed cage floor. This platform was placed there to enable foxes easy entry from the shed cage floor to the earthen floor.

\section{Video recordings and analyses}

Behaviour of experimental foxes was video-recorded using the video system comprised of eight black-white video cameras (Computar FC 55) equipped with wide-angle lenses, two quads (Computar QS-MX) enabling each simultaneous recording from the four cameras to a time-lapse video-recorder (Hitachi VT-L2000E) and two black-white monitors (Computar CEM-12). Videograms were recorded at a frequency of 1.25 per second. During dark hours each cage was lit with two dim red lights (Philips E27ES, $60 \mathrm{~W}$ ). The experiment started on Friday at 1200 when the experimental animals were individually 
Korhonen, H. et al. Effect of enlarged cage space on blue foxes

placed into the smallest test cages. Test animals were allowed to become accustomed to the test environment until Monday (0900) when the actual recordings began. Video recordings ended on Saturday at 0900 (5-d continuous recordings) and were resumed the following Monday (0900) for a further 5 days. Thus, each animal was recorded for 10 working days in each experimental cage option. Cage size was enlarged after a 2-wk period on Saturday morning at 0900. Thus, animals were always allowed time to adapt to the next option over the weekend.

The video tapes were analyzed by two persons (a continuous recording method; Martin and Bateson 1986) by a video tape recorder (JVC video casette recorder HR-D560E) and a TV monitor (Philips). The following behaviours were identified: 1) locomotor activity: animal moving on its legs; 2) inactivity: not moving (rest, sit, stand); and 3) digging: performing digging behaviour with fore pads. The occurence of these behaviour patterns was analysed according to option where they were performed (cage floor, ground floor). Variables formed for statistical analyses were in each option: 1) the total time spent for a specific behaviour; 2) the mean bout length; and 3) circadian distribution (working hours 0700-1500 vs. all other times).

\section{Statistical methods}

Study days 29 (large cage) and 33 (large cage with access to earthen floor) were totally omitted from the data because of electrical disturbances during the video recordings. The same problem forced data to be eliminated from day 35 (large cage with access to earthen floor) concerning one fox. Consequently an extra day (41) was videorecorded for this fox and included to the data.

For each fox there were repeated measurements in four different cages. Any two observations for a given fox were correlated and this correlation was taken into account on the selected models. The covariance structure of the repeated measurements was chosen by comparing several potential structures by Akaike's information criterion and Schwarz's Bayesian criterion (Wolfinger 1996). Both analyses of activity level were based on the following model:

$\mathrm{Y}_{\mathrm{ij}}=\mu+\rho_{\mathrm{i}}+\tau_{\mathrm{j}}+\mathrm{e}_{\mathrm{ij}}$

where $Y_{i j}$ is the locomotor activity for fox $i$ in cage $j, \mu$ is a constant, $\rho$ is the effect of fox considered to be random, $\tau$ is the effect of cage considered fixed and $\mathrm{e}_{\mathrm{ij}}$ are error terms. Model (1) assumes the following: $\rho_{\mathrm{i}}$ are independent and normally distributed with mean 0 and variance $\sigma_{\mathrm{p}}^{2}, \Sigma \tau_{\mathrm{j}}=0, \mathrm{e}_{\mathrm{ij}}$ are independent and normally distributed with mean 0 and variance $\sigma^{2}$. The model is equivalent with the standard model of the randomized complete block design with a compound symmetry covariance structure. Assumptions of the models were checked using graphical methods: box-plot for normality of errors and plots of studentized residuals against fitted values for constancy of error variance (Neter et al. 1996). It was also determined that differences between persons analyzing video tapes were not significant. Parameters of the models were estimated by the restricted maximum likelihood (REML) estimation method.

Duration of recorded activity bouts for each fox was divided into three categories: short (1$2 \mathrm{~min}$ ), medium (3-6 min) and long (>7 min). Categories are referred to as $\mathrm{S}, \mathrm{M}$ and $\mathrm{L}$, respectively. The sum of percentage of these three groups is $100 \%$ for a given fox and cage. Such data are known as compositional data and they were analysed according to Aitchison (1986) by defining two logrations: $\log (\mathrm{S} / \mathrm{L})$ and $\log (\mathrm{M} / \mathrm{L})$. Ternary-diagrams were drawn to confirm analytical conclusions.

Comparisons between means of cages were made by planned orthogonal contrasts and t-type $95 \%$ confidence intervals (CI). Statistically, orthogonal means that the sums of squares for the two contrasts are independent. Thus, all orthogonal contrasts are independent of each other and any multiple comparison procedures are unnecessary.

Statistical analyses were performed using the SAS system for Windows release 6.12 by the 
Vol. 8 (1999): 253-263.

following procedures: MIXED, GLM (SAS 1996), UNIVARIATE (SAS 1990a) and GPLOT (SAS 1990b).

\section{Results}

\section{Locomotor activity}

Initial examination of experimental data by graphs revealed a significant variation in the amount and duration of activity between individuals. Only a slight difference was found between study days which justified pooling the days within each cage option.

Mean daily time spent in locomotion ranged from $304 \mathrm{~min} / 24 \mathrm{~h}$ in large cage to $330 \mathrm{~min} / 24 \mathrm{~h}$ in large cage with access to an earthen floor (Fig. 2). No statistically significant differences in activity rates between different cage options were found $\left(F_{3,21}=0.15, P=0.93\right)$. After this general test, data was further examined by orthogonal contrasts. The $95 \%$ confidence intervals (CI) were calculated for different options. If the CI included zero, it implied that the difference was not statistically significant at the 5\% level. First, it was clarified if locomotor activity was different in wire-mesh floored shed cages (pooled options small cage, medium cage, large cage) compared to earthen floor cage. However, no differences were found with a $95 \%$ confidence interval ( $\mathrm{CI}$ : $-86,+48, \mathrm{~F}_{1.21}=0.34, \mathrm{P}=0.56$ ). A second interesting comparison was that of the smallest wire-mesh floored cage versus the larger wire-mesh floored cages (pooled options medium cage, large cage) which similarly did not show any significant differences (CI: $-65,+78$, $\left.\mathrm{F}_{1,21}=0.04, \mathrm{P}=0.85\right)$. The conclusion was the same when comparing the largest wire-mesh floored cage versus the medium cage $(\mathrm{CI}:-93,+72$, $\mathrm{F}_{1,21}=0.07, \mathrm{P}=0.80$ ).

Duration of an activity bout was first analyzed as a 3-dimensional variable by means of two logrations. The relationship between short (1-2 $\mathrm{min})$ and long (>7 $\mathrm{min})$ bouts tended to

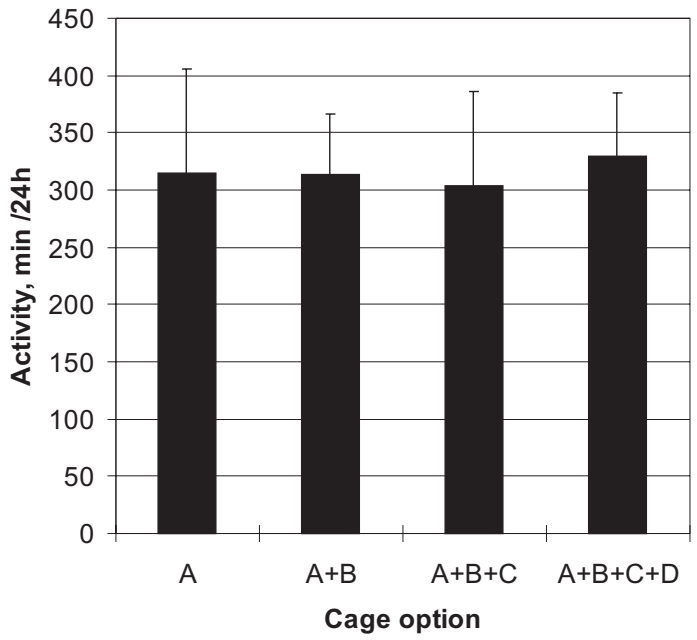

Fig. 2. Locomotor activity of farmed blue foxes in different cage options. Results are as least square means with standard deviations. For explanation of cage options see Fig. 1.

be different between various cage options $\left(\mathrm{F}_{3,42}=2.55, \mathrm{P}=0.07\right)$. No statistical difference was detected in the relationship between medium (3$6 \mathrm{~min})$ and long bouts $\left(\mathrm{F}_{4,42}=1.46, \mathrm{P}=0.24\right)$. The result was quite similar by ternary-diagrams. Examination of data by the above means confirmed that the relationship between medium and long bouts remained unchanged despite changes in the duration of activity. Thus, it allowed these two bout classes to be pooled without any loss of actual information. This enabled further analysis of data by the model (1) (where $\mathrm{Y}_{\mathrm{ij}}$ was the duration of $3 \mathrm{~min}$ or longer active bouts in percentage). Finally, the present results were calculated by each study model the findings of which were consistent between both approaches.

Duration of an active bout was typically very short. As Fig. 3 shows, almost half of locomotor activity in all experiments was no longer than 2 minutes in duration. In addition, data analyses revealed that $75 \%$ of bouts were no longer than 6 minutes. A marked trend was found $\left(\mathrm{F}_{3,21}=2.96\right.$, $\mathrm{P}=0.05)$ that duration of activity bout varied between cage options. Duration of bout in the 


\section{AGRICULTURAL AND FOOD SCIENCE IN FINLAND}

Korhonen, H. et al. Effect of enlarged cage space on blue foxes

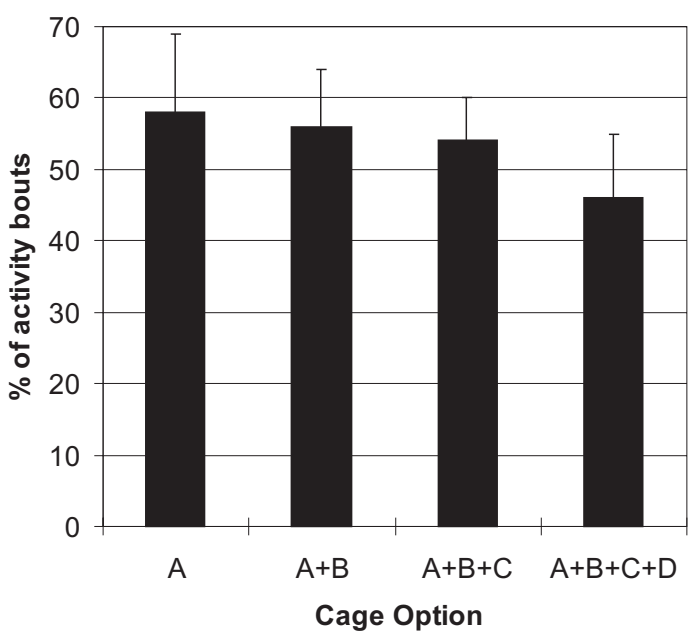

Fig. 3. Percentage of activity bouts (least square means with standard deviations ) lasting 3 min or longer. For cage options see Fig. 1.

pooled options small cage, medium cage, large cage was significantly longer than that in large cage with access to an earthen floor $(\mathrm{CI}:+3,+18$, $\left.\mathrm{F}_{1,21}=7.98, \mathrm{P}=0.01\right)$. On average, it was $10 \%$ in favour of former options. Bout lengths in small cage did not differ from those in pooled medium and large cage options (CI: $-5,+11$, $\left.\mathrm{F}_{1,21}=0.51, \mathrm{P}=0.48\right)$ and, correspondingly, the bout length in medium cage did not differ from that of large cage $\left(\mathrm{CI}:-7,+12, \mathrm{~F}_{1,21}=0.35\right.$, $\mathrm{P}=0.56)$.

\section{Floor preference and digging}

Only three out of eight foxes visited the ground level during the first study week. Their stay there was occasional and did not occur each day. During the second study week, however, six foxes out of eight were observed to visit the earthen floor. These visits occurred daily. Besides moving, foxes were occasionally seen resting on the ground (Fig. 4). However, the resting frequency

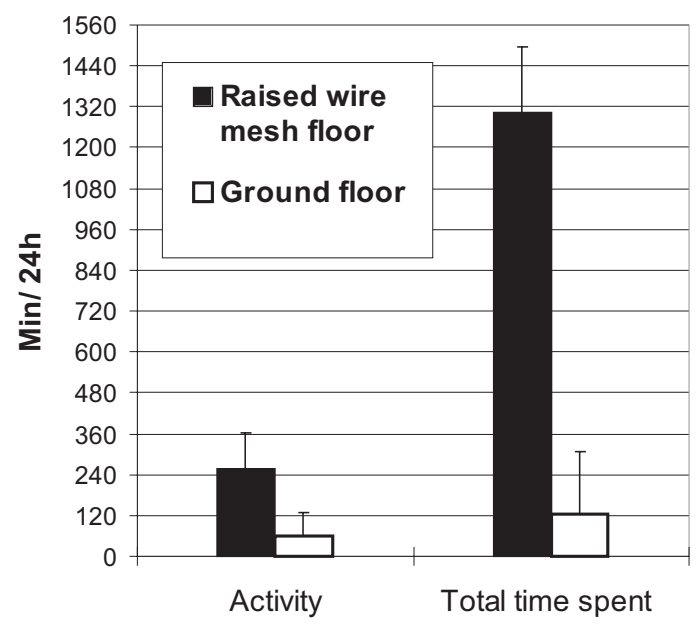

Fig. 4. Comparison of locomotor activity and total time spent between a raised wire-mesh floor (option $\mathrm{A}+\mathrm{B}+\mathrm{C}$ ) and an earthen floor on the ground (option D). Results are as least square means with standard deviations.

was very low and three out of the total of eight foxes did not rest on the ground at all. On average, foxes spent $77.6 \%(\mathrm{sd}=18.9)$ and $19.1 \%$ $(\mathrm{sd}=17.2)$ of activity at shed and ground level, respectively. In addition, $3.3 \%(\mathrm{sd}=0.3)$ of time was used for rapid activity back and forth between shed cage floor and earthen level. In large cage, $55 \%(\mathrm{sd}=8)$ of all activities on the shed cage floor occurred during working hours (07001500.). The corresponding percentage for the earthen floor was only $34 \%$ ( $\mathrm{sd}=14)$.

Digging behaviour was not observed at all for the shed cage options. After providing foxes with a free access to the earthen level, all three individuals visiting the ground floor during the first study week were observed to dig. One of these dug 27 min during two days and another one dug 191 min during the first three days of access to earthen floor. The third fox was observed to dig during the first three days (total 70 min). During the second week digging frequency was even less because only two foxes were seen digging. Total digging times were 6 and 10 min, respectively. 
Vol. 8 (1999): 253-263.

\section{Discussion}

Behavioural restriction can impair animal welfare, for example, because motivation to perform certain behavior can remain high even if an animal is unable to perform it. One method of studying motivational tendency to perform a behaviour is to measure its rebound effect. An increased tendency for performance after a period of prevention indicates that the behaviour is influenced by internal causal factors and that these accumulate when prevented from performing the behaviour (Lorenz 1981, Petherick and Rushen 1997). In the present study, it was assumed that if a small cage prevents a fox from performing an adequate level of locomotor activity, it will cause it to perform it at a higher frequency once a fox has an opportunity in a larger cage. The present results, however, showed that enlargement of cage size had no substantial effect on the amount of locomotion. No activity rebound did thus exist. Interpretation of this result is that the small cage was not greatly restrictive with regard to locomotor activity.

Previous studies on space requirements of canids that are about the same body size as farmed blue foxes are available. Neamand et al. (1975) observed no differences in the physical activity of beagle dogs housed in cages measuring $120 \mathrm{~cm}$ long x $60 \mathrm{~cm}$ wide x $75 \mathrm{~cm}$ high vs those housed in $120 \mathrm{~cm}$ long x $240 \mathrm{~cm}$ wide $\mathrm{x}$ $120 \mathrm{~cm}$ high cages. Hite et al. (1977) found that the size of the standard cage $(75 \mathrm{~cm}$ long $\mathrm{x} 75$ $\mathrm{cm}$ wide $\mathrm{x} 75 \mathrm{~cm}$ high) appeared adequate for beagle dogs and no advantage was found when dogs were housed in larger cages $(225 \mathrm{~cm}$ long $\mathrm{x} 75 \mathrm{~cm}$ wide $\mathrm{x} 75 \mathrm{~cm}$ high) with respect to behaviour, patterns of activity or health. Correspondingly, Campbell et al. (1988) and Hughes et al. (1989) found no differences in the physical activity of beagle dogs housed either in $1 \mathrm{~m}$ x $1 \mathrm{~m}$ or $1 \mathrm{~m}$ x $2 \mathrm{~m}$ cages. In farmed raccoon dogs, locomotor activity was of the same order of magnitude in small cages $(60 \mathrm{~cm}$ long x 105 $\mathrm{cm}$ wide $\mathrm{x} 60 \mathrm{~cm}$ high) as in large cages (240 cm long x $105 \mathrm{~cm}$ wide x $60 \mathrm{~cm}$ high) (Korho- nen and Harri 1988). The above mentioned examples support the conclusion of the present study, i.e. enlargement of cage space does not increase locomotor activity as measured by time spent for locomotion.

Duration of activity bouts can be considered one quality indicator for locomotor activity. If the housing environment is restrictive with respect to locomotion, it enables animals to only move in very short bursts. In a restrictive environment animals may also develop stereotypies. The present results showed that activity bouts were typically no longer than 1-5 minutes in duration for all experimental options. This might be an indication of certain difficulties to perform long-lasting activity in cages. The alternative explanation is that activity bouts lasting 1-5 minutes are typical patterns of movement, not only for captive but also wild foxes. Unfortunately, slight comparative data are available on bout lengths of foxes in seminatural and wild conditions, and the occurrence of stereotypies was not measured in the present study. Previously, it has been found that the amount of stereotypies in medium farm cage measuring $115 \mathrm{~cm}$ long x $105 \mathrm{~cm}$ wide $\mathrm{x} 70 \mathrm{~cm}$ high is very slight, i.e. only 26 min per $24 \mathrm{~h}$ (Wikman et al. 1998).

Fourth cage option provided foxes possibility for choices between wire-mesh and earthen floors. It can be expected that the choice of where to walk and rest is due to comfort, i.e. sensory feedback from feet and ventral surface. Thus, if farmed blue foxes experience wire-mesh flooring as unpleasant they will try to avoid it. The result of foxes' floor preference was distinct: they gave a high priority to wire-mesh flooring. Only a few hours per day were spent on the earthen floor. Probable explanation for this preference is that farmborn blue foxes have become accustomed to living on wire-mesh flooring and do not consider it an uncomfortable floor material. This conclusion is also supported by previous studies of Korhonen and Niemelä (1997) and Skovgaard et al. (1995, 1997), in which blue foxes born on wire-mesh cages neither did reject wire-mesh flooring altough a solid floor was available. Additional interpretation for floor 


\section{AGRICULTURAL AND FOOD SCIENCE IN FINLAND}

\section{Korhonen, H. et al. Effect of enlarged cage space on blue foxes}

preference in the present study can be that preference was more associated with the location of the wire-mesh cage than to a previous living history on wire-mesh floor or its superiority as a floor material. Namely, farmed foxes are known to have a preference for an unobstructed view of surroundings and for elevated places (Mononen et al. 1995, Korhonen and Niemelä 1996b). This affords a greater possibility to watch and control their environment. Furthermore, preference for high places seems to be independent of floor material (Harri et al. 1996). The earthen floor cage in the present study was located at ground level with a low positioning to man and a restricted view. According to the present circadian activity results foxes' visits on ground level occurred mostly outside working hours, i.e. when no farm personnel were present. On ground level, foxes undoubtly felt less safe compared to the raised wire-mesh level.

Previous experience may have an effect on the establishment and loss of the preferences expressed by an animal. Animals may show a temporary avoidance of, or attraction to, an unfamiliar option (Fraser and Matthews 1997). Typically the effect of early experience rapidly vanishes with a loss of novelty or reaches a certain level with increasing familiarity. In the present study the duration of the experiment was sufficient for both novelty responses. During the first study week, three out of eight foxes visited the ground option, but during the second week the visitation of foxes was increased to 6 out of eight. Thus, it is possible that foxes initially avoided the ground option because they had no previous experience prior to the current experiment. With respect to digging behaviour, the amount was slight during the entire study while three and two out of eight foxes were seen to dig during the first and second week, respectively. Exposure time for ground contact was two weeks which should be sufficient firstly to eliminate novelty and secondly motivate digging if the need to dig was crucial or dammed-up.

The recommendations of the European Convention (1991) imply that the needs for rest, observation and seclusion should be satisfied in order to enhance welfare of farm foxes. Furthermore, they also mention that foxes are terrestrial animals which are known to dig in the wild. The recommendations emphasize that in the design of new housing conditions for farm foxes, behavioural characteristics and their inherent needs should be better taken into account. The general assumption that foxes should be allowed to dig also in farm conditions is based on this European paragraph. Unfortunately, the recommendations do not specify the details of the concept "need for digging" in farm foxes. Therefore, at least two different aspects of digging can be separated. Firstly, digging as a behavioural need per se and, secondly, need to dig for a certain specific purpose. Only limited research data is available concerning these two aspects of digging in foxes (Jeselnik and Brisbin 1980, Korhonen and Alasuutari 1994, Kronholm 1994). In dogs, however, more data on digging behaviour and characteristics have been documented . Digging is often not appreciated and can be considered more or less a behavioural problem (Bonnie and Beaver 1987, Adams and Grandage 1989, Odendaal 1996). Therefore, several effective means to prevent dogs from digging have been described. Digging by dogs can occur for a number of reasons and can be modified by genetics and environment. It appears that dogs do not dig because digging is a need per se, but digging typically has a specific purpose. Certain points of contacts with foxes can be found. For example, wild red foxes (Jeselnik and Brisbin 1980) and penned blue foxes (Kronholm 1994) similar to dogs are known to bury extra food for later use. In dogs, the solution to this problem is to supply just enough food for the dog to consume at a time (Odendaal 1996). Farmed blue foxes are not fed on excessive amounts of feed. Therefore, farmed blue foxes do not have an actual reason to bury food. Digging by dogs can also be associated with the preparation of a nest for whelping. Provision of a proper whelping box on time is well known method of preventing nest digging behaviour (Odendaal 1996). Den digging is known also in wild and penned blue 
Vol. 8 (1999): 253-263.

foxes (Korhonen and Alasuutari 1994). On farms, foxes are provided wooden nestboxes before whelping which can be assumed to eliminate the nest digging pattern. After all, one crucial question evokes, namely, that do farmed foxes have a need to dig in the absence of stimuli? In the present study, foxes were given the opportunity to perform digging behaviour, the frequency of which was used as a measure of digging motivation. However, no specific digging stimuli except the earthen floor was provided. The results showed that the amount of digging was slight and infrequent, indicating that foxes in the absence of stimuli are not particularly motivated to dig.
Acknowledgements. This study was a part of a comprehensive joint project entitled Alternative Housing Environment for Farmed Foxes that involved collaboration between the Fur Farming Research Station of Kannus (MTT), Department of Applied Zoology \& Veterinary Medicine from the University of Kuopio, the Finnish Society for the Protection of Animals and the Finnish Fur Breeders' Association. The study was supported financially by the European Union (via Seinäjoki TE keskus), the International Fur Trade Federation and the Finnish Fur Breeders' Association. Great thanks to Mrs. Elisa Tavasti, Mrs. Tellervo Suikkola and Mrs. Tiina Huuki for analysing the video tapes and to Mr. Pekka Siirilä for computer assistance. Thanks are due to Mr. Pekka Eskeli and Mr. Jaakko Huuki for conducting the video recordings and Mr. Pekka Toikkanen, Mr. Aimo JokiHuuki and Mr. Terho Lindqvist for their diligent care of the animals.

\section{References}

Adams, G.J. \& Grandage, J. 1989. Digging behaviour in domestic dogs. Australian Veterinary Journal 66: 126.

Aitchison, J. 1986. The Statistical Analysis of Compositional Data. Chapman and Hall, London. 341 p.

Appleby, M.C. \& Wood-Gush, D.G.M. 1988. Effect of earth as an additional stimulus on the behaviour of confined pigs. Behavioural Processes 17: 83-91.

Bakken, M., Braastad, B., Harri, M., Jeppesen, L.L. \& Pedersen, V. 1994. Production conditions, behaviour and welfare of farm foxes. Scientifur 18: 233-248.

Berg, H. 1986. Rehutietoutta turkiseläinkasvattajille. Turkiseläintutkimuksia 23. Suomen Turkiseläinten Kasvattajain Liitto ry. Vaasa. $99 \mathrm{p}$.

Bonnie, V. \& Beaver, B.S. 1987. The digging dog. The Southwestern Veterinarian 38: 35-36.

Braastad, B.O. 1992. Progress in the ethology of foxes and mink. Norwegian Journal of Agricultural Sciences, Supplement 9: 487-504.

Campbell, S.A., Hughes, H.C., Griffin, H.E., Landi, M.S. \& Mallon, F.M. 1988. Some effects of limited exercise on purpose-bred beagles. American Journal of Veterinary Research 49: 1298-1301.

European Convention 1991. European Convention for the Protection of Animals Kept for Farming Purposes, Strasbourg 1976, ETS 87. Recommendation Concerning Fur Animals, 25 June 1991. 19 p.

Fraser, D. \& Matthews, L.R. 1997. Preference and motivation testing. In: Appleby, M.C. \& Hughes, B.O. Animal Welfare. CAB International, Wallingford, Oxon, UK. p. 159-173.

Harri, M., Mononen, J., Korhonen, H. \& Haapanen, K. 1991. A study of the use of resting platforms by farmbred blue foxes. Applied Animal Behaviour Science 30: 125-139.

-, Kasanen, S., Mononen, J., Ahola, L. \& Rekilä, T. 1996.
Do farmed silver foxes prefer solid floor? Animal Production Review, Applied Science Reports 29: 59-64.

Hite, M., Hanson, H.M., Bohidar, N.R., Conti, P.A. \& Mattis, P.A. 1977. Effect of cage size on patterns of activity and health of beagle dogs. Laboratory Animal Science 27: 60-64.

Hughes, H.C., Campbell, S. \& Kenney, C. 1989. The effects of cage size and pair housing on exercise of beagle dogs. Laboratory Animal Science 39: 302305.

Jeselnik, D.L. \& Brisbin, I.L. 1980. Food-caching behaviour of captive-reared red foxes. Applied Animal Ethology 6: 363-367.

Korhonen, H. \& Harri, M. 1988. Effect of cage size on growth, feed intake, fur quality and activity pattern of farmed raccoon dogs. Zeitschrift für Versuchstierkunde 31: 49-54.

- \& Alasuutari, S. 1994. Social relationships and reproductive performance in group-living arctic blue foxes. Agricultural Science in Finland 3: 49-58.

- \& Niemelä, P. 1994. Preferences of silver and blue foxes for farm cage and pen. NJF-meeting nr. 253, Rebild, Denmark, 28-30th of September, 1994. $16 \mathrm{p}$.

-, Ketoja, E. \& Niemelä, P. 1995. Comparison of daytime use between platform types, materials, ceilings and experiences in juvenile blue foxes (Alopex lagopus). Applied Animal Behaviour Science 45: 125-138.

-, Niemelä, P. \& Tuuri, H.1996. Seasonal changes in platform use by farmed blue foxes (Alopex lagopus). Applied Animal Behaviour Science 48: 99-114.

- \& Niemelä, P. 1996a. Seasonal changes in platform use by adult farmbred silver foxes (Vulpes vulpes). Agricultural and Food Science in Finland 5: 3-15.

- \& Niemelä, P. 1996b. Comparison between the use 
Korhonen, H. et al. Effect of enlarged cage space on blue foxes

of open and walled platforms by juvenile blue foxes (Alopex lagopus). Agricultural and Food Science in Finland 5: 177-184.

- \& Niemelä, P. 1996c. Temperament and reproductive success in farmbred silver foxes housed with and without platforms. Journal of Animal Breeding and Genetics 113: 209-218.

- \& Niemelä, P. 1997. Choices of farm foxes for raised wire mesh cage and ground pen. Applied Animal Behaviour Science 54: 243-250.

- \& Niemelä, P. 1998. Seasonal and circadian changes in activity rates of adult farm blue foxes. Agricultural and Food Science in Finland 7: 21-29.

-, Jauhiainen, L. \& Niemelä, P. 1998. Effect of increased cage length on locomotor activity of juvenile blue foxes (Alopex lagopus). Scientifur 22: 23-27.

Kronholm, A. 1994. Sexual differences in parental investment and behaviour during weaning in arctic foxes, Alopex lagopus, in a semi-natural environment. Institution för husdjurshygien. Specialarbete 20. Skara, Sweden. 43 p.

Lorenz, K. 1981. The Foundations of Ethology. Springer, New York. 152 p.

Martin, P. \& Bateson, P. 1986. Measuring Behaviour: An Introductory Guide. 2nd Edition, Cambridge University Press, London, UK. 222 p.

Mononen, J., Harri, M., Rekilä, T., Korhonen, H. \& Niemelä, P. 1995. Use of nest boxes by young farmed silver foxes (Vulpes vulpes) in autumn. Applied Animal Behaviour Science 43: 213-221.

-, Korhonen, H.\& Harri, M. 1996. Resting platforms for farmed foxes - a short review. Animal Production Reviews, Applied Science Reports 29: 65-69.

Neamand, J., Sweeny, W.T., Creamer, A.A. \& Conti, P.A. 1975. Cage activity in the laboratory beagle: a preliminary study to evaluate a method of comparing cage size and physical activity. Laboratory Animal Science 25: 180-183.
Neter, J., Kutner, M., Nachtsheim, C. \& Wasserman, W. 1996. Applied Linear Statistical Models. Fourth Edition. Irwin, Chicago. $1310 \mathrm{p}$.

Odendaal, J.S.J. 1996. An ethological approach to the problem of dogs digging holes. Applied Animal Behaviour Science 52: 299-305.

Petherick, J.C. \& Rushen, J. 1997. Behavioural restriction. In: Appleby, M.C. \& Hughes, B.O. Animal Welfare. CAB International, Wallingford, Oxon, UK. p. 89107.

SAS Institute Inc 1990a. SAS Procedures Guide, Version 6. Third Edition. SAS Institute Inc., Cary, NC. $705 \mathrm{p}$.

- 1990b. SAS/GRAPH Software: Reference, Version 6. First Edition, Volume 2. SAS Institute Inc., Cary, NC. $1342 \mathrm{p}$.

- 1996. SAS/STAT Software: Changes and Enhancements through Release 6.11. SAS Institute Inc., Cary, NC. $1104 \mathrm{p}$.

Skovgaard, K., Pedersen, V. \& Jeppesen, L.L. 1995. Praeference för forskellige bundtyper hos blåraeve. NJF-meeting, Gothenbourg, Sweden, 4-6th October, 1995. $5 \mathrm{p}$.

-, Pedersen, V. \& Jeppesen, L.L. 1997. The preference for different types of floor in silver foxes and blue foxes. Nordic ISAE-meeting in Kuopio, Finland, 1012th January, 1997. (abstract).

Wiegand, R.M., Gonyou, H.W. \& Curtis, S. E. 1994 . Pen shape and size: effects on pig behaviour and performance. Applied Animal Behaviour Science 39: 4961.

Wikman, I., Mononen, J., Rekilä, T. \& Harri, M. 1998. Stereotypies hos unga farmrävar. NJF seminar nr. 295. Bergen, Norge, 7-9th September, 1998. 6 p.

Wolfinger, R. 1996. Heterogeneous variance-covariance structures for repeated measures. Journal of Agricultural, Biological, and Environmental Statistics 1: 205-230. 
Vol. 8 (1999): 253-263.

\title{
SELOSTUS
}

\section{Häkkikoon ja maakontaktin vaikutus sinikettujen liikunta- ja kaivamisaktiviteettiin}

\author{
Hannu Korhonen, Lauri Jauhiainen ja Paavo Niemelä \\ Maatalouden tutkimuskeskus
}

Tässä työssä tutkittiin asteittain suurennetun häkkikoon ja maakontaktin vaikutusta tarhakettujen liikunta- ja kaivamisaktiviteettiin. Kahdeksan viikon pituinen koejakso ajoittui touko-kesäkuuhun. Kokeessa oli kahdeksan aikuista sinikettua (Alopex lagopus), jotka viettivät kaksi ensimmäistä viikkoa pienessä häkissä (80 cm pitkä x $105 \mathrm{~cm}$ leveä x $70 \mathrm{~cm}$ korkea). Sen jälkeen häkin pituus lisättiin $120 \mathrm{~cm}$ :iin. Kahden viikon kuluttua häkki suurennettiin edelleen $240 \mathrm{~cm}: n$ pituuteen. Neljäntenä vaihtoehtona ketut pääsivät 2 viikon kuluttua häkkiin $(80 \mathrm{~cm}$ pitkä x $105 \mathrm{~cm}$ leveä x $70 \mathrm{~cm}$ korkea), joka sijaitsi suoraan isoimman häkin alla. Tässä vaihtoehdossa ketuilla oli mahdollisuus viettää aikaansa joko ylhäällä verkkohäkkiosalla ja/tai alhaalla maapohjaosalla. Kussakin häkkiko- kovaihtoehdossa kettujen käyttäytyminen kuvattiin videokameralaitteiston avulla. Oletettiin, että jos pienin häkki rajoittaa ketun liikunta-aktiviteettia, niin suuremmissa häkeissä ketuilla on parempi mahdollisuus liikkua. Tämän tulisi ilmetä lisääntyneenä liikunta-aktiviteettina. Tulokset osoittivat, ettei ketun liikunta-aktiviteetti eikä aktiivisuusjakson pituus kasvanut häkkikoon kasvaessa. Neljännessä vaihtoehdossa vertailtiin kettujen mieltymystä ylhäällä olevaa varjotalohäkkiä ja alhaalla olevaa maapohjaa kohtaan. Ketut suosivat selvästi varjotalohäkkiä. Kettujen kaivamisaktiviteettia tutkittiin maapohjahäkissä. Tulokset osoittivat, että ketut eivät olleet erityisen motivoituneita kaivamaan. 
